American Journal of Environmental Sciences 7 (6): 525-530, 2011

ISSN 1553-345X

(C) 2011 Science Publications

\title{
Impact of Abattoir and Saw-Mill Effluents on Water Quality of Upper Ogun River (Abeokuta)
}

\author{
Adeogun, A.O., A.V. Chukwuka and O.R. Ibor \\ Department of Zoology, Faculty of Science, \\ University of Ibadan, Ibadan, Nigeria
}

\begin{abstract}
Problem statement: The unregulated discharge of contaminants from point sources into inland freshwater aquatic systems and the resultant deterioration of water quality are largely undocumented in developing countries like Nigeria especially with respect to the role of seasonal factors on the recovery capacity of aquatic systems. Approach: The aim of this study was to assess the impact of abattoir and saw-mill industry effluents on the physicochemical properties of Upper Ogun River (Abeokuta) Nigeria. Bi-monthly sampling was carried out using three sampling points upstream and downstream of the point source of discharge over a period of six months (wet and dry season). Water samples were analyzed using standard procedures. The parameters determined were: Temperature, $\mathrm{pH}$, Electrical Conductivity (EC), Total Solids (TS), Total Suspended Solids (TSS), Total Dissolved Solids, Phosphate $\left(\mathrm{PO}_{4}{ }^{3-}\right)$, Nitrate $\left(\mathrm{NO}_{3}{ }^{-}\right)$, Chloride $\left(\mathrm{Cl}^{-}\right)$, Dissolved Oxygen (DO), Biochemical Oxygen Demand (BOD) and Chemical Oxygen Demand (COD). Results: The mean values of Temperature, BOD, COD, TS, TDS, TSS, $\mathrm{PO}_{4}{ }^{3-}, \mathrm{NO}_{3}{ }^{-}, \mathrm{Cl}^{-}$were significantly higher $(\mathrm{p}<0.05)$ during the dry season compared to the wet season. It was also observed that the DO values were higher during the wet season compared to the dry season. Recovery studies as a measure of the self-purification capacity of Upper Ogun River to the abattoir and saw-mill effluents being received showed that Chloride recorded the highest recovery value downstream from the point discharge. All the parameters studied except Temperature, $\mathrm{pH}$ and Chloride exceeded the water quality standards for fisheries and aquatic life specified by the National Environmental Standards and Regulations Enforcement Agency (NESREA) and the World Health Organization (WHO) maximum permissible standards for drinking water. Conclusion/Recommendations: The recovery capacity of river Ogun shows a strong dependence on seasonal changes. The elevated values of the physicochemical parameters are of concern with regards to the possible effects on sustainable fisheries in this river, if such pollution trends remain unchanged. It is therefore imperative that compliance of industries to standards and regulations on the use of the environment should be enforced.
\end{abstract}

Key words: Industrial effluent, water quality, upper ogun river, quality standards, industrial effluents, self-purification capacity, season compared, point discharge, developing countries

\section{INTRODUCTION}

Industrialization presents unprecedented challenges to the health and integrity of aquatic ecosystems as a result of contamination from effluent discharge (Vutukuru, 2005; Naji and Ismail, 2011). In contrast to what obtains in some developed countries (Neal and Robison, 2000), environmental monitoring in many developing countries is faced with challenges of operationalization and enforcement of environmental laws, standards and treaties thus the indiscriminate use of aquatic systems as receptacles of industrial wastes. Incidences of freshwater contamination have been reported in several cities in Nigeria (Adebisi, 1981; Onianwa, 1993; Olajire and Imeokparia, 2001; Fakayode, 2005; Arimoro et al., 2007; Chukwu et al., 2007; Osibanjo and Adie, 2007; Chukwu et al., 2008; Chukwu, 2008; Yakub and Ugwumba, 2009) yet little is known about the effect of point effluent discharge on water quality and the recovery capacity of numerous rivers and streams in the country.

There is also limited information on accumulation studies of some elements and its significance in determining the self-purification mechanisms of rivers. This study is thus aimed at evaluating the effect of point discharge of abattoir and saw-mill effluents on the water quality of Upper Ogun River, Abeokuta, Nigeria.

Corresponding Author: Adeogun, A.O., Department of Zoology, Faculty of Science, University of Ibadan, Ibadan, Nigeria 


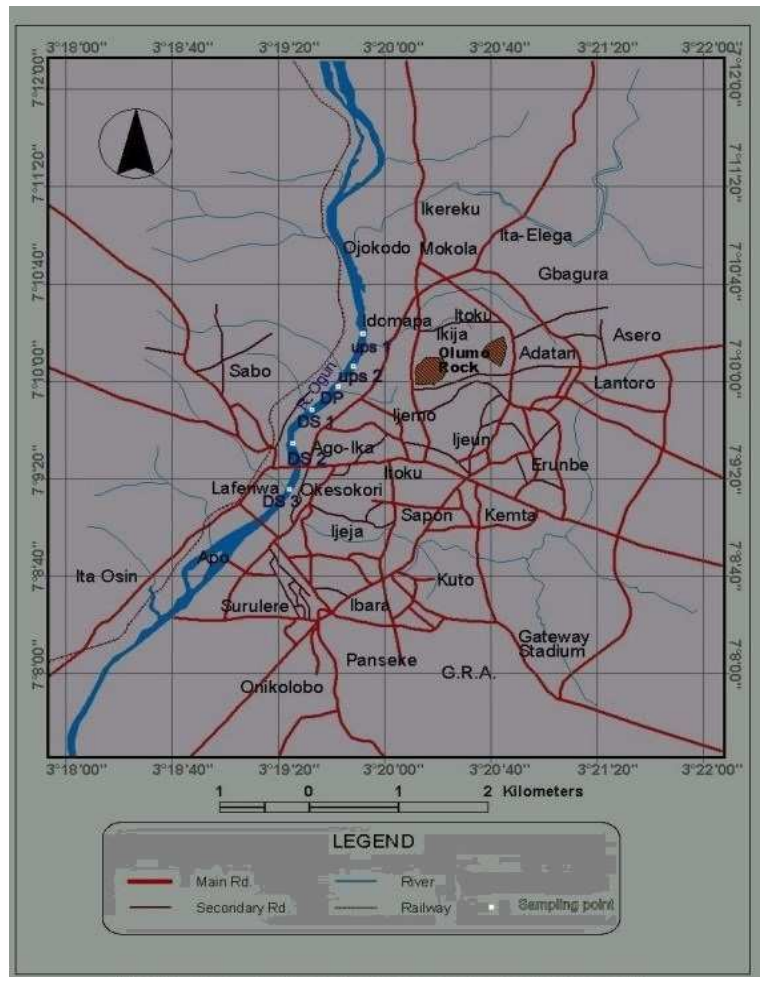

Fig. 1: Map of Ogun River with sampling points

Study area: Ogun River is one of the two principal rivers in the Ogun-Osun River Basin of Nigeria with the characteristics of a tropical climate. It flows from Ogun-Osun river basin through Abeokuta in Ogun state and empties into the Lagos lagoon of Nigeria. The river supports major artisanal fishery activity especially in Ogun and Lagos States of Nigeria. It has coordinates of $3^{\circ} 28 \mathrm{E}$ and $8^{\circ} 41 \mathrm{~N}$ from its source in Oyo state to $3^{\circ} 25$ $\mathrm{E}$ and $6^{\circ} 35 \mathrm{~N}$ in Lagos where it enters the Lagos lagoon. The area represents a typical rainforest belt with rainy season starting from April through November and dry season commencing from December through March (Adebisi, 1981). The stretch of the river considered i.e., the Upper Ogun river was chosen relative to the location of the point of discharge (Fig. 1).

\section{MATERIALS AND METHODS}

Water sampling and analysis: Effluents from an abattoir and a saw-mill are channeled directly into Upper Ogun River forming a point source. The point of discharge was chosen as a reference point and water samples were collected bi-monthly across the dry (February-March) and wet (April-July) season. Water upstream (Ups) were sampled at two sampling locations before the point of discharge at a distance of $250 \mathrm{~m}$ apart. Water samples were also collected Downstream (Ds) after the point of discharge at three different sampling locations at $250 \mathrm{~m}$ interval from one another. The water chemical analysis was done using standard analytical methods of water analysis (Eaton and Franson, 2005). Non-conservable parameters such as, temperature, $\mathrm{pH}$ and electrical conductivity were determined at the time of sampling in the field. The $\mathrm{pH}$ of the sample was measured with a $\mathrm{pH}$ meter that has been previously calibrated with buffer solutions and conductivity was measured with a conductivity meter calibrated with potassium chloride solution. Dissolved Oxygen (DO) was determined by Winkler's titration. The dissolved oxygen contents of the water samples were fixed by addition of Winkler's A (manganous sulphate solution) and Winkler's B (alkali-iodide) reagents to the sample. The samples were transported to the laboratory where they were titrated with a standard sodium thiosulphate solution. Total Solid (TS) was determined gravimetrically by evaporating a known volume of water sample to dryness in a preweighed crucible on a steam bath at $105^{\circ} \mathrm{C}$. Nitrate was determined using phenol disulphunic acid method (Marczenko, 1986). Chloride (Cl-) was analyzed by titrating a known volume of water sample with standardized $0.014 \mathrm{~N}$ mercuric (II) nitrate solution. Phosphate (PO43-) was determined colorimetrically by ascorbic acid-molybdenum blue method (Eaton and Franson, 2005).

Recovery studies: The degree of Recovery Capacity (RRC) for Upper Ogun River was calculated using the formula adapted from (Ernestova and Semanova, 1994) as modified by (Fakayode, 2005) given as:

$$
\left(\mathrm{S}_{0}-\mathrm{S}_{1}\right) / \mathrm{S}_{0} \times 100 \text {, Expressed in \% }
$$

Where:

$\mathrm{S}_{0}=$ Average level of parameters downstream (i.e., immediately after the discharge point)

$S_{1}=$ Average level of parameters upstream where there is no pollution

The degree of contamination as a result of effluent discharge was estimated by the Accumulation Factor (AF). Accumulation Factor (AF) is the ratio of the average level of a given parameter downstream after the point discharge to the corresponding average level upstream (Fakayode, 2005).

Data were analyzed using SPSS version 17 package. Mean values of physicochemical parameters were compared to water quality standards and guidelines specified by NESREA and WHO respectively. 


\section{RESULTS}

Ogun River was observed to be clear and transparent before the point of discharge, but was turbid and had a pungent odour at the point of discharge. During the dry season (February-March) the water level at the stretch of the river studied was low with some parts of the river forming pools thus being somewhat lentic; but with the onset of the rains in April, the water level increased and the river was lotic. The mean seasonal physico-chemical variations across all sampling points are shown in Table 1. The Temperature of water upstream and downstream were normal with no significant increase $(\mathrm{p}<0.05)$ during the wet season. The $\mathrm{pH}$ levels ranged from 5.50 $\pm 0.14-8.60 \pm 0.07$ with no significant increase $(\mathrm{p}<0.05)$ during the wet season. Acidic pH (5.50) was recorded at the Discharge point (Dp). DO values ranged from $0.00 \pm 0.00-11.27 \pm 0.21 \mathrm{mg}$ $\mathrm{L}^{-1}$. No DO $\left(0.00 \pm 0.00 \mathrm{mg} \mathrm{L}^{-1}\right)$ was detected at the Discharge point (Dp) during the dry season. DO values where higher during the wet season compared to the dry season. There was a significant decrease in the DO values $(\mathrm{p}<0.05)$ between upstream and downstream values across the dry and wet season. BOD values ranged from $79.25 \pm 1.42-686.53 \pm 0.74 \mathrm{mg} \mathrm{L}^{-1}$. COD values ranged from $181.50 \pm 1.50-1374.91 \pm 0.15 \mathrm{mg} \mathrm{L}^{-1}$. TS values ranged from $1172.40 \pm 0.10-2252.50 \pm 3.53 \mathrm{mg}$ $\mathrm{L}^{-1}$. TDS values ranged from 346.05 $\pm 0.63-757.03 \pm 0.14$ $\mathrm{mg} \mathrm{L}^{-1}$. TSS values ranged from $822.93 \pm 0.10-$ $1495.47 \pm 0.77 \mathrm{mg} \mathrm{L}^{-1}$. Nitrate values ranged from $12.28 \pm 0.47-88.45 \pm 1.34 \mathrm{mg} \mathrm{L}^{-1}$. Phosphate values ranged from $1.85 \pm 0.18-18.62 \pm 0.28 \mathrm{mg} \mathrm{L}^{-1}$. Chloride values ranged from $15.33 \pm 1.32-183.58 \pm 4.40 \mathrm{mg} \mathrm{L}^{-1}$ and EC values ranged from 725.19 $\pm 0.76-3400.00 \pm 0.00$ $\mu \mathrm{Scm}^{-3}$. The concentrations of BOD, COD, TDS, TSS, TS, EC, $\mathrm{PO}_{4}{ }^{3-}, \mathrm{Cl}^{-}, \mathrm{NO}_{3}{ }^{-}$in the samples showed significant increase $(\mathrm{P}<0.05)$ between upstream and downstream values across the wet and dry season. Higher concentrations of Temperature, BOD, COD, TS, TDS, TSS, EC and $\mathrm{PO}_{4}{ }^{3-} \mathrm{Cl}^{-}, \mathrm{NO}_{3}{ }^{-}$were recorded during the dry season compared to the wet season, while DO values were higher during the wet season compared to the dry season.

The percentage recovery capacity of the physicochemical parameters are presented in Fig. 2. Dissolved Oxygen (DO) recorded no recovery $(0 \%)$ in the dry season (February and March). Accumulation factor of some physico-chemical parameters are presented in Fig. 3. Chloride recorded the highest accumulation factor of $6.32 \%$ during the dry season, while Nitrate was the least accumulated downstream with an accumulation factor of $1.24 \%$ during the dry season. In the rainy season there was a sharp drop in chloride accumulation and a gradual increase in nitrate and phosphate accumulation.

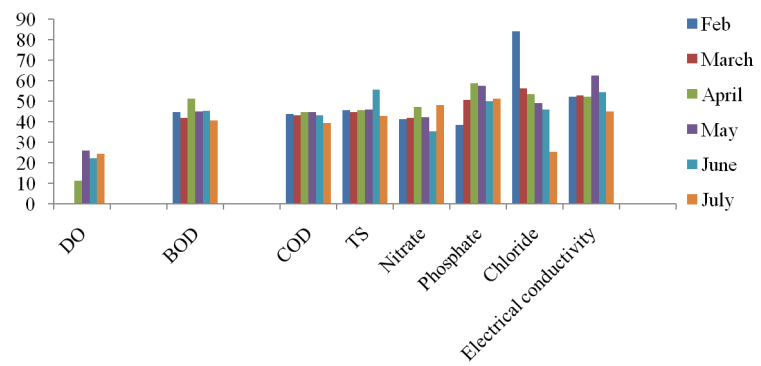

Fig. 2: Percentage recovery capacity of Physicochemical parameters of upper ogun river

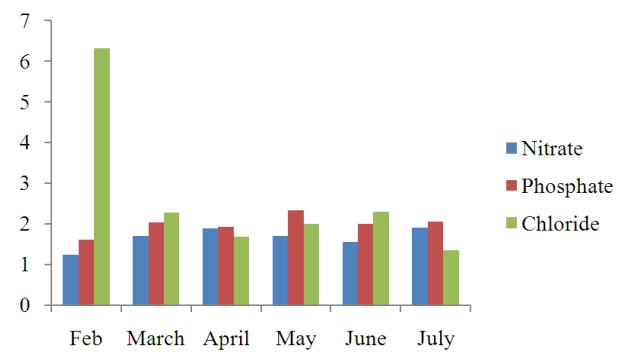

Fig. 3: Accumulation factors of some physico-chemical parameters of upper ogun river

Table 1: Mean values of physicochemical parameters of upper Ogun River at various sampling locations across the dry and wet season

\begin{tabular}{|c|c|c|c|c|c|c|c|c|c|c|c|c|}
\hline & Temp $\left({ }^{\circ} \mathrm{C}\right)$ & $\mathrm{pH}$ & DO (mg/L) & BOD (mg/L) & $\mathrm{COD}(\mathrm{mg} / \mathrm{L})$ & TS (mg/L) & TDS (mg/L) & TSS (mg/L) & Nitrate $(\mathrm{mg} / \mathrm{L})$ & Phosphate $(\mathrm{mg} / \mathrm{L})$ & Chloride (mg/L) & $\mathrm{EC}\left(\mu \mathrm{S} \mathrm{cm}^{-3}\right)$ \\
\hline \multicolumn{13}{|l|}{ Dry season } \\
\hline Ups 1 & $29.50 \pm 0.70$ & $8.15 \pm 0.01$ & $4.07 \pm 0.01$ & $345.10 \pm 0.01$ & $699.49 \pm 0.46$ & $1256.50 \pm 3.53$ & $346.05 \pm 0.63$ & $910.45 \pm 3.47$ & $51.60 \pm 0.70$ & $8.02 \pm 0.21$ & $46.50 \pm 0.55$ & $1571.0 \pm 1.41$ \\
\hline Ups 2 & $30.50 \pm 0.70$ & $8.05 \pm 0.07$ & $2.05 \pm 0.02$ & $486.75 \pm 0.49$ & $972.90 \pm 0.28$ & $1586.50 \pm 0.70$ & $545.05 \pm 1.48$ & $1041.09 \pm 0.77$ & $88.45 \pm 1.34$ & $12.63 \pm 0.02$ & $113.89 \pm 1.43$ & $1753.00 \pm 4.24$ \\
\hline $\mathrm{Dp}$ & $32.00 \pm 0.00$ & $5.5 \pm 0.14$ & $0.00 \pm 0.00$ & $686.53 \pm 0.74$ & $1374.91 \pm 0.15$ & $2252.50 \pm 3.53$ & $757.03 \pm 0.14$ & $1495.47 \pm 0.77$ & $89.43 \pm 0.68$ & $18.62 \pm 0.28$ & $183.58 \pm 4.41$ & $3400.00 \pm 0.00$ \\
\hline Ds 1 & $31.00 \pm 0.00$ & $6.60 \pm 0.14$ & $1.03 \pm 0.01$ & $587.80 \pm 0.14$ & $1174.17 \pm 0.36$ & $2042.50 \pm 3.53$ & $629.77 \pm 0.49$ & $1412.73 \pm 3.58$ & $88.43 \pm 0.74$ & $12.02 \pm 1.95$ & $160.06 \pm 0.85$ & $2862.50 \pm 3.53$ \\
\hline Ds 2 & $30.50 \pm 0.70$ & $6.95 \pm 0.07$ & $2.03 \pm 0.00$ & $486.65 \pm 0.36$ & $972.50 \pm 0.42$ & $1791.50 \pm 2.12$ & $578.15 \pm 5.59$ & $1213.34 \pm 3.47$ & $87.13 \pm 0.14$ & $11.87 \pm 1.73$ & $123.50 \pm 0.57$ & $2347.00 \pm 0.72$ \\
\hline Ds 3 & $30.00 \pm 0.00$ & $7.45 \pm 0.07$ & $3.06 \pm 0.07$ & $412.80 \pm 0.13$ & $824.17 \pm 0.14$ & $1400.50 \pm 0.70$ & $388.17 \pm 1.69$ & $1003.33 \pm 0.74$ & $64.70 \pm 1.70$ & $9.50 \pm 0.14$ & $82.06 \pm 0.84$ & $1752.50 \pm 3.53$ \\
\hline \multicolumn{13}{|l|}{ Wet season } \\
\hline Ups 1 & $24.00 \pm 0.00$ & $8.60 \pm 0.07$ & $11.27 \pm 0.21$ & $79.25 \pm 1.42$ & $181.50 \pm 1.54$ & $1172.40 \pm 0.10$ & $349.47 \pm 0.24$ & $822.93 \pm 0.10$ & $12.28 \pm 0.47$ & $1.85 \pm 0.18$ & $15.33 \pm 1.32$ & $725.19 \pm 0.76$ \\
\hline Ups 2 & $25.00 \pm 0.00$ & $8.80 \pm 0.07$ & $10.20 \pm 0.06$ & $97.65 \pm 0.31$ & $257.94 \pm 1.70$ & $1254.35 \pm 2.62$ & $396.56 \pm 0.78$ & $857.60 \pm 1.09$ & $28.90 \pm 0.41$ & $3.80 \pm 0.21$ & $32.15 \pm 0.56$ & $963.60 \pm 7.30$ \\
\hline $\mathrm{Dp}$ & $25.5 \pm 0.70$ & $7.10 \pm 0.14$ & $6.70 \pm 0.26$ & $113.24 \pm 1.31$ & $466.40 \pm 1.70$ & $1886.51 \pm 1.70$ & $638.85 \pm 2.05$ & $1247.70 \pm 0.36$ & $34.20 \pm 0.00$ & $5.18 \pm 0.01$ & $35.81 \pm 0.42$ & $1806.70 \pm 21.42$ \\
\hline Ds 1 & $25.00 \pm 0.00$ & $7.70 \pm 0.14$ & $8.30 \pm 0.26$ & $104.16 \pm 2.50$ & $314.30 \pm 1.28$ & $1631.70 \pm 1.75$ & $536.50 \pm 1.40$ & $1095.21 \pm 3.15$ & $30.71 \pm 0.30$ & $4.75 \pm 0.19$ & $26.80 \pm 1.24$ & $1303.87 \pm 1.95$ \\
\hline Ds 2 & $25.00 \pm 0.00$ & $8.35 \pm 0.07$ & $9.44 \pm 0.16$ & $98.62 \pm 1.50$ & $216.52 \pm 1.32$ & $1359.25 \pm 0.07$ & $491.95 \pm 0.62$ & $867.30 \pm 0.56$ & $26.28 \pm 0.09$ & $4.12 \pm 0.13$ & $20.40 \pm 1.42$ & $904.08 \pm 4.33$ \\
\hline Ds 3 & $24.50 \pm 0.00$ & $8.05 \pm 0.07$ & $10.71 \pm 0.16$ & $95.06 \pm 2.20$ & $195.20 \pm 0.68$ & $1255.61 \pm 7.22$ & $392.79 \pm 4.86$ & $862.85 \pm 12.09$ & $21.64 \pm 0.16$ & $2.72 \pm 0.34$ & $17.56 \pm 0.09$ & $858.72 \pm 0.10$ \\
\hline \multicolumn{13}{|c|}{ 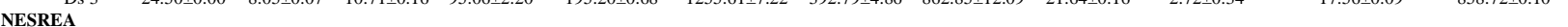 } \\
\hline stand ards & - & $6.5-8.50$ & $>=6.00$ & 3.00 & 6.00 & - & - & 0.25 & 9.10 & 3.50 & 300.00 & - \\
\hline WHO standards & $<40^{\circ} \mathrm{C}$ & $6.50-8.50$ & 4.00 & - & $<1.0 .00$ & 2000.00 & 250.00 & - & 10.00 & 5.00 & 250.00 & 500.00 \\
\hline
\end{tabular}




\section{DISCUSSION}

As depicted in Table 1 temperature values were within the range for a tropical aquatic system $\left(<40^{\circ} \mathrm{C}\right)$. The alkaline $\mathrm{pH}$ values recorded upstream falls within the recommended range suitable for aquatic life. $\mathrm{pH}$ is an indicator of water quality and the extent of pollution (Jonnalagadda and Mhere, 2001) thus the acidic values at the discharge point suggests that the effluent negatively impacted the water quality and this could consequently affect aquatic life negatively because most of their metabolic activities are $\mathrm{pH}$ dependent (Chen and Lin, 1995). The observed acidity maybe as a result of humic acid formed from decaying organic matter from wood shavings. This is in line with reports from (Rim-Rukeh et al., 2006) on Orogodo River implying that decaying organic matter contributes to humic acid formation.

Dissolved oxygen concentration in natural waters depends on the physical, chemical and biochemical activities in the water body. DO values recorded during the dry season were lower than the NESREA (2011) and WHO (1993) water quality standards. This could be attributed to the high levels of nutrients, organic loads and total solids content of effluents from these industries and the lentic nature of the river during the dry season. DO is very crucial for the survival of aquatic organisms (Yakub and Ugwumba, 2009). DO was not detected at the discharge point during the dry season and this may be due to the high levels of nutrients and total suspended solids contents of the effluents. The depletion of DO at the Discharge Point (DP) could also be connected to the enormous amount of organic loads which required high levels of oxygen for chemical oxidation, decomposition of nutrients or break down thereby depleting available oxygen required for respiration. Similar findings have been reported from Minna River receiving abattoir effluent (Chukwu et al., 2008) and Ethiope river receiving saw mill effluent (Arimoro et al., 2007). However, a profound increase in DO was recorded from April with the onset of the rains; this we believe could be as a result of increased dilution by rain water.

The highest Dissolved Oxygen (DO) value recorded upstream during the wet season could be due to the high transparency allowing for sufficient sunlight penetration causing an increase in photosynthetic activity within the aquatic system. Similar findings were reported by Arimoro et al. (2007) in River Ethiope, Niger Delta. The decomposition of wood waste by microbial activities exerts high biochemical oxygen demand and creates anaerobic conditions resulting in the introduction of bacteria and pathogens into the river and eutrophication stimulating nutrients like nitrate and phosphate (Jonnalagadda and Mhere, 2001). Moreover, high BOD values at the discharge point could be attributed to the low DO level, since low DO will result in high BOD and this is a strong indication of pollution (Chukwu et al., 2007). The Chemical Oxygen Demand (COD) was higher than the NESREA (2011) and WHO (1993) values recommended for good water quality. The high COD compared to BOD values recorded in this study may have resulted from organic substances not oxidize-able by aerobic bacteria. Also this may be due to the fact that most organic substances are ultimately broken down anaerobically or chemically; thus COD measures all the oxidizable organics while BOD measures the oxygen available for biological activities. Also, high COD value at the discharge point could be due to high organic load of Total Solid and Total Suspended Solid from these industries. This could probably explain the linear relationship between solids and COD (Osibanjo and Adie, 2007). It is worthy to note that the COD values downstream (after the point of effluent discharge) were low. This could be attributed to net dilution and decomposition of organic load as they move away from the point of discharge. The COD values recorded in this study was low compared to several findings. Osibanjo and Adie (2007) recorded a COD range of 947-2566 $\mathrm{mg} \mathrm{L}^{-1}$ from Oshunkaye stream receiving Bodija abattoir but this study recorded a range of $195.20^{-1} 174.17 \mathrm{mg} \mathrm{L}^{-1}$. This could be due the fact that the rate of serial dilution in a River is high when compared to that of streams. Also the large surface area and volume of Ogun River compared to Oshunkaye stream could explain the differences in the COD values observed.

In addition to run-off of storm water from surrounding land during the rainy season, the high levels of TS, TDS and TSS observed may also be attributed to deposition of wood shavings from the abattoir and saw-mill industry. The continuous deposition of solid particles from these industries could lead to a reduction in volume of water by impeding the free flow of the river. Long term deposition of materials into Ogun river may also result in flooding, particularly during heavy rain fall which could have both economic and ecological implications (Fakayode, 2005). Electrical Conductivity (EC) which is a measure of conducting ionic elements in a sample solution was recorded in high levels at the discharge point. The observed values could be attributed to the high levels of conducting elements such as chloride and phosphate. (Fakayode, 2005) reported a similar observation and noted that conducting elements contributed to the high 
electrical conductivity in Alfaro stream. Nitrate values were above the 9.10 and $10.00 \mathrm{mg} \mathrm{L}^{-1}$ values for good water quality standard specified by NESREA and WHO. Possible sources of nitrogenous wastes include partially digested food from the gut of slaughtered animals washed into the river.

The high level of phosphate in the water samples could be due to the leaching of fertilizer residues from agricultural farms along the river. This probably could be responsible for the abundance of phytoplankton observed along the river banks. Other sources of chloride and phosphate may be from detergents used by the abattoir workers to wash roasted slaughtered animals (Osibanjo and Adie, 2007), laundry activities of surrounding residents and run-off of house hold effluents into the river (Fakayode, 2005).

An in-depth knowledge of the concentration of pollutants in any effluent receiving river or stream is necessary to properly evaluate its natural recovery capacity or self purification ability i.e., the dynamics with which pollutants are removed, redistributed, decomposed or transformed to harmless substances as it flows downstream from the point of pollution. Selfpurification capacity of a water body is a good indicator of its ecological status (Ernestova and Semanova, 1994). It involves complex mechanism which depends on several factors such as flow rate, time, temperature, serial dilution, chemical oxidation, biodegradation of organic materials, deposition of solid or particulate materials into sediment, dilution of contaminants, presence of micro organisms, $\mathrm{pH}$ and dissolved oxygen content of the water. The nature of contaminants among other factors plays a significant role on the degree or extent of recovery of an aquatic system. Thus the high rate of recovery downstream from the point of effluent discharge especially for parameters like phosphate and nitrate may be as a result of their nutrient value to algae and other aquatic plants. The lack of recovery in dissolved oxygen during the dry season (February and March) could be due to the seasonal lentil nature of the river coupled with the continuous deposition of effluents into the river. Fakayode (2005) reported similar findings in Alaro stream receiving effluents from agrochemical, paper mill and food and packaging industries. The increase in recovery capacity of dissolved oxygen in April (at the onset of the rainy season) could be due to the increase in water level resulting in a high rate of dilution of effluents by the rains. The high accumulation and low recovery capacity for chloride compared to other nutrients like phosphate and nitrate recorded may be attributed to household laundry activities along the length of the river.

\section{CONCLUSION}

From this study it is evident that the water quality of Upper Ogun River was adversely affected and impaired by effluents discharges from the abattoir and saw-mill industries; the alteration in water quality was more pronounced in the dry season compared to the wet season. The levels of parameters downstream were significantly elevated than the corresponding levels upstream. The recovery capacity over the stretch of the studied river section was not good indicating that Upper Ogun River is under constant pollution from abattoir and saw-mill industrial effluents. The quality of the effluent discharges clearly exceeded acceptable limits prescribed by law.

It is pertinent that the concerned environmental regulatory body in Nigeria (NESREA) needs to device mechanisms to enforce existing environmental laws concerning the discharge of effluents from different sources. Such effort will go a long way in ensuring an appreciable reduction in contamination of surface waters and ensure their suitability for domestic and industrial use/usage.

\section{ACKNOWLEDGEMENT}

The researchers hereby acknowledge the MacArthur foundation start up Research Grant for female faculty for providing funds for this research.

\section{REFERENCES}

Adebisi, A.A., 1981. The physico-chemical hydrology of a tropical seasonal river-upper Ogun River. Hydrobiologia, 79: 157-165. DOI: 10.1007/BF00006123

Arimoro, F.O., M.A. Chukwudi and O. Ogheneghalome, 2007. Effect of industrial waste water on the physical and chemical characteristics of a tropical coastal river. Res. J. En. Sci., 2: 209-220.

Chen, J.C. and C.Y. Lin, 1995. Responses of oxygen consumption, Ammonia-N excretion and Urea-N excretion of Penaeus chinensis exposed to ambient ammonia at different salinity and $\mathrm{pH}$ levels. J. Agric., 136: 243-255. DOI: 10.1016/00448486(95)01060-2

Chukwu, O., 2008. Analysis of groundwater pollution from abattoir waste in Minna, Nigeria. Res. J. Dairy Sci., 2: 74-77.

Chukwu, O., E.S.A. Ajisegiri, K.R. Onifade and O.D. Jimoh, 2007. Environmental impact auditing of food processing industry in Nigeria: The case of climate and air quality. AU J. T., 11: 77-85. 
Chukwu, O., H.I. Mustapha and H.B.A. Gafar, 2008. The effect of Minna abattoir waste water on surface water quality I. Environ. Res. J., 3: 334-338.

Eaton, A.D. and M.A.H. Franson, 2005. Standard Methods for the Examination of Water and Wastewater. 21st Edn., American Public Health Association, Washington, DC., ISBN: 0875530478.

Ernestova, L.S. and L.V. Semanova, 1994. The selfpurification of the ecological state of a water body. J. Water Res., 21: 146-150.

Fakayode, S.O., 2005. Impact assessment of industrial effluent on water quality of the receiving Alaro stream in Ibadan, Nigeria. J. Ajeam-Ragee, 10: 1-13.

Jonnalagadda, S.B. and G. Mhere, 2001. Water quality of the odzi river in the eastern highlands of Zimbabwe. Water Res., 35: 2371-2376. DOI: 10.1016/S0043-1354(00)00533-9

Marczenko, Z., $1986 . \quad$ Separation and Spectrophotometric Determination of Elements. 2nd Edn., E. Horwood, Chichester, ISBN: 0853129037, pp: 678.

Naji, A. and A. Ismail, 2011. Assessment of Metals Contamination in Klang River Surface Sediments by using Different Indexes. Environ. Asia, 4: 30-38.

Neal, C. and A.J. Robison, 2000. A summary of river water quality data collected within the Land-Ocean Interaction Study: Core data for eastern UK rivers draining to the North Sea. Sci. Total Environ., 251252: 585-665. DOI: 10.1016/S00489697(00)00397-1

NESREA, 2011. National Environmental (Surface and Groundwater quality) Regulations. National Environmental Standards and Regulations Enforcement Agency.
Olajire, A.A. and F.F. Imeokparia, 2001. Water quality assessment of osun river: Studies on inorganic nutrients. Environ. Monit Assessment, 69: 17-28. DOI: 10.1023/A:1010796410829

Onianwa, P.C., 1993. Environmental Pollution Studies in an Underdeveloped Country: (1) Heavy Metal Pollution in Ibadan, Nigeria. Environ. Educ. Inform., 12: 25-34.

Osibanjo, O. and G.U. Adie, 2007. Impact of effluent from Bodija abattoir on the physico-chemical parameters of Oshunkaye stream in Ibadan City, Nigeria. Afr. J. Biotechnol., 6: 18061-811.

Rim-Rukeh, A., O.G. Ikhifa and A.P. Okokoya, 2006. Effects of agricultural activities on the water quality of orogodo river, Agbor Nigeria. J. Applied Sci. Res., 2: 256-259.

Vutukuru, S.S., 2005. Acute effects of hexavalent chromium on survival, oxygen consumption, hematological parameters and some biochemical profiles of the indian major carp, Labeo rohita. Int. J. Environ. Res. Public Health. 2: 456-462. DOI: 10.3390/ijerph2005030010

WHO, 1993. Guidelines for Drinking-Water Quality. 2nd Edn., World Health Organization, Geneva, ISBN: 9241545038, pp: 1399.

Yakub, A.S. and A.A.A. Ugwumba, 2009. A study on the macroinvertebrate fauna of lower Ogun River at Ishasi, Ogun state, south-west Nigeria. Zoologist, 7: 65-74. 